\title{
Rize Illinde Çocuk Hastalarda Hepatit A, B ve C Seroprevalansı
}

\author{
Seroprevelance of HAV, HBV, HCV in Pediatric Patients in Rize City
}

\author{
Ayşegül ÇOPUR ÇIÇEK1, Serdar ÖZKASAP2, Selim DEREC|2, Kazım ŞAHIN1, \\ Deniz Zehra ULUSAN GÜNDOĞDU1, Aziz Ramazan DILEK1, Ayşe ERTÜRK3 \\ ${ }^{1}$ Recep Tayyip Erdoğan Üniversitesi Tıp Fakültesi, Tıbbi Mikrobiyoloji Anabilim Dall, Rize, Türkiye \\ 2Recep Tayyip Erdoğan Üniversitesi Tıp Fakültesi, Çocuk Hastalıkları Kliniği, Rize, Türkiye \\ ${ }^{3}$ Recep Tayyip Erdoğan Üniversitesi Tıp Fakültesi, Enfeksiyon Hastalıkları ve Klinik Mikrobiyoloji Anabilim Dalı, Rize, Türkiye
}

\section{ÖZET}

Amaç: Bu çalıșmanın amacı Rize ilindeki çocuk hastalarda şu ana kadar araștııımamış olan hepatit A, B ve C seropozitiflik oranını belirlemek, ülkemizin diğer bölgeleri ile karşılaşıırmak ve çocuk hastalarda sınırlı sayıdaki epidemiyolojik çalışmalara katkı sağlamaktır.

Gereç ve Yöntemler: Rize Eğitim ve Araştırma Hastanesi pediatri servis ve polikliniklerine 01.01.2010-31.12.2011 tarihleri arasında farklı șikayetlerle başvurmuş 0-16 yaş grubu hastalar çalışmaya alındı. Enzyme Linked Immunosorbend Assay (ELISA) yöntemi ile (Abbott Architect) üretici firmanın önerileri doğrultusunda calısıldı. Anti-HAV lgM, Anti-HAV lgG, HBsAg, Anti-HBs, Anti-HBclgM ve $G$ ile Anti-HCV testleri retrospektif olarak incelendi.

Bulgular: Calısmaya alınan 1173 cocuk hastanın 748'ü (\%63,8) erkek 425'sı $(\% 36,2)$ kız idi. Yaşları 0 ile 17 arasında olup, yaş ortalaması 5,61 $\pm 4,21$ yıl idi. AntiHAV IgG seropozitifliği \%29,5 (202/684) ve Anti-HAV IgM pozitifliği \%2,5 (17/682) olarak saptandı. Birlikte pozitiflik \%3,8 oranı ile 7 hastada tespit edildi. Anti-HAV IgG seropozitifliği olan 202 hastadan 107'si erkek (\%53), 95'i kızdı (\%47). Cinsiyet bakımından aradaki fark istatistiksel olarak anlamlı bulundu $(\mathrm{p}<0,0001)$. Toplam 1173 çocuk hastanın HBsAg, Anti-HBs, AntiHBclg M, AntiHBclg G ve Anti-HCV seropozitifllikleri değerlendirildiğinde; sırasıyla $\% 2,4, \% 79,4, \% 0,5, \% 10,1$ ve $\% 0,6$ olarak saptandı. HBsAg ve Anti-HBs birlikte pozitifliği sadece 3 hastada tespit edildi. Hiçbir çocukta Anti-HIV pozitifliği görülmedi. HAV, HBV ve HCV için değişik yas grupları arasında seropozitiflik oranları yönünden anlamlı bir fark olmadı̆̆ı görülmüştür. Haziran 1998'de ulusal aşı programının başlamasılyla birlikte Anti-HBc Ig $G$ ve Anti-HBs pozitifliği 1998'den sonra doğanlarda daha yüksek olduğu görülmüș ve istatistiksel olarak da anlamlı bulunmuştur.

Sonuç: Bu çalışmada; HAV için aşılamanın yanı sıra eğitimle birlikte sanitasyon tedbirlerinin etkin bir sekilde kullanılması ve altyapı eksikliklerinin giderilmesi HAV enfeksiyonun görülme oranını azaltacağı vurgulanmıştır. Ayrıca hepatit $B$ ve hepatit $C$ seroprevalans oranları, ülkemizdeki genel nüfus oranlarıyla uyumludur. Ülkemizde çocukluk çağında HBV ve HCV seroprevalansıyla ilgili daha fazla çalışma yapılmalıdır. "Ulusal Hepatit B Aşı Programı" (UHBAP) uygulamasında hedef değerlere ulaşılması için toplumun daha da bilinçlendirilmesi gerekmektedir. (Viral Hepatit Dergisi 2012; 18(3): 102-6)

Anahtar kelimeler: HAV, HBV, HCV, seroprevalans, çocukluk yaş grubu

\section{ABSTRACT}

Objective: Determining of seroprevalence of hepatitis $A, B$ and $C$ among pediatric age group in Rize province, comparing with the other regions of country and contribute to the limited number of epidemiological studies in this group.

Materials and Methods: The study was performed between 01.01.201031.12.2011 in pediatric age group between 0-16 years old with different complaints admitted to Rize Training and Research Hospital. ELISA technique was used and Anti-HAV lgM, anti-HAV IgG, HBsAg, anti-HBs, Anti-HBclgM and $\mathrm{G}$ with the anti-HCV tests were analyzed retrospectively.

Results: 1173 children were analyzed (748 male, 425 female). Anti-HAV lgG seropositivity and Anti-HAV IgM positivity were $29.5 \%$ and $2.5 \%$ respectively. Both Anti-HAV IgM and Anti-HAV IgG seropositivity were detected in 7 patients. In 202 patients were determined Anti-HAV IgG seropositivity (107 male, 95 female). Gender difference was statistically significant $(p<0.0001)$. HBsAg, anti-HBs, Anti-HBclgM, Anti-HBclgG and anti-HCV seropositivity of 1173 pediatric patients were detected as $2.4 \%, 79.4 \%, 0.5 \%, 10.1 \%$ and $0.6 \%$ respectively. Only 3 patients were positive both HBsAg and anti-HBs in. No anti-HIV positivity was determined. HAV, HBV and HCV seropositivity rates among different age groups were not significantly different. Starting of the national immunization program in June 1998, the Anti-HBs and Anti-HBc IgG positivity was seen to be higher in subjects born after 1998 and it was statistically significant.

Conclusion: The vaccination for HAV infection, as well as education, sanitation measures, together with efficient use of infrastructure and elimination of deficiencies will reduce the incidence of HAV infection. Besides, HBV and HCV seroprevalence rates in our country are compatible with the general population rates. More studies are needed about HBV and HCV seroprevalance for childhood. National hepatitis B vaccination program need to raise awareness in society further in order to achieve the target values. (Viral Hepatitis Journal 2012; 18(3): 102-6)

Key words: HAV, HBV, HCV, seroprevalence, the pediatric age group

Yazışma Adresi/Address for Correspondence: Dr. Ayşegül Çopur Çiçek, Recep Tayyip Erdoğan Üniversitesi Tıp Fakültesi, Tıbbi Mikrobiyoloji Anabilim Dalı, Rize, Türkiye Tel.:+90 4642123009 E-mail: draysegulcicek@yahoo.com Geliș tarihi/Received: 20.08.2012 Kabul tarihi/Accepted: 02.11.2012

(c) Viral Hepatit Dergisi, Galenos Yayınevi tarafindan basılmıștır. IViral Hepatitis Journal, published by Galenos Publishing. 


\section{Giriş}

Enfeksiyöz hepatit olarak da adlandırılan Hepatit A RNA virüsü olan bir pikornavirüs tarafından oluşturulur, dışkı-ağız yoluyla bulaşır, yaklaşık bir ay süren bir inkübasyon dönemi vardır ve ikterik semptomlar bu dönemin ardından birdenbire ortaya çıkar, kronikleşmez ve nadiren öldürücüdür (1). Hepatit B infeksiyonunun, parenteral (kan veya kan ürünleri transfüzyonu, steril olmayan iğne ve enjektörlerin ortak kullanımı, sağlık personeline kaza ile enfekte enjektör iğnesi batması, ortak kullanılan traş bıçakları), perinatal (annenin taşıyıcı olması sonucu travayda veya doğum sırasında amnion sıvısının veya plasenta yırtıklarından sızan anne kanının yutulması), horizontal (aile içi yakın temas, yetersiz hijyenik durumlar, aynı havlunun, sakızın veya diş fırçasının paylaşılması) ve cinsel temas (homoseksüel veya heteroseksüel cinsel ilişkiler) gibi bulaşma yolları vardır. Anneden bebeğe geçiş, perinatal yolla (vertikal yol) veya özellikle aile içi yakın temasla, horizontal yolla enfekte olma ise çoğunlukla süt çocukları veya 5 yaşından küçük çocuklarda görülür (2-5). 2,3,4 nolu kaynak az sayıdaki hasta grubunu içermektedir.

Hepatit B ve C virüs (HBV, HCV) enfeksiyonları halen ülkemizde önemli bir sağlık sorunudur. Yapılan çalışmalarda tüm dünyada hepatit B taşıyıcııı̆ı oranı \%0,1-20 arasında değişmekle beraber ortalama \%5, hepatit C taşıyıcılığı oranı \%1-5 arasında değişmekle beraber ortalama \%3 olarak bildirilmiştir. Türkiye'de hepatit B taşıyıcılığı \%4-10, hepatit C taşıyıcılığı \%0,3-1,8 olarak gösterilmiştir $(6,7)$.) (5 nolu kaynak özel bir hasta grubundaki az bir hasta sayısını içermektedir. Türkiye genelini ifade edemez. Bu çalışmada Rize ilindeki çocuk hastalarda şu ana kadar araştııımamış olan hepatit A, $B$ ve $C$ seropozitiflik oranını belirlemek, ülkemizin diğer bölgeleri ile karşılaştırmak ve çocuk hastalarda sınırlı sayıdaki epidemiyolojik çalışmalara katkı sağlamaktır.

\section{Gereç ve Yöntem}

Rize Eğitim ve Araştırma Hastanesi pediatri servis ve polikliniklerine 01.01.2010-31.12.2011 tarihleri arasında farklı şikayetlerle başvurmuş 0-16 yaş grubu hastalar çalışmaya alındı. Enzyme Linked Immunosorbend Assay (ELISA) yöntemi ile (Abbott Architect, $A B D)$ üretici firmanın önerileri doğrultusunda çalışıldı. Anti-HAV IgM, Anti-HAV IgG, HBsAg, Anti-HBs, Anti-HBc IgM ve G ile Anti-HCV testleri retrospektif olarak incelendi. Verilerin incelenmesi SPSS 18.0 paket programında yapıldı. Sonuçlar sayı ve yüzde olarak ifade edildi. Karşılaştırrmalarda ki kare testi kullanıldı. $\mathrm{p}<0,05$ olan değerler istatistiksel olarak anlamlı kabul edildi.

\section{Bulgular}

Çalışmaya alınan 1173 çocuk hastanın 748'ü (\%63,8) erkek 425'sı $(\% 36,2)$ kız idi. Yaşları 0 ile 17 arasında olup, yaş ortalaması

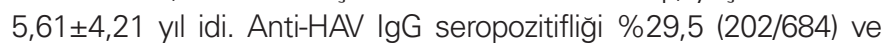
Anti-HAV IgM pozitifliği \%2,5 (17/682) olarak saptandı. Birlikte pozitiflik \%3,8 oranı ile 7 hastada tespit edildi. Anti-HAV IgG seropozitifliği olan 202 hastadan 107'si erkek (\%53), 95'i kıdı (\%47). Cinsiyet bakımından aradaki fark istatistiksel olarak anlamlı bulundu $(p<0,0001)$. Anti-HAV IgM pozitif hastaların $(n=17) 10^{\prime} u$ erkek (\%58,8), 7'si kızdı (\%41,2). Cinsiyet bakımından aradaki fark istatistiksel olarak anlamlı değildi.
Çocuk hastaların 0-3, 4-7, 8-11 ve 12-16 yaş gruplarına göre AntiHAV IgM ve Anti-HAV IgG pozitifliklerine bakıldığında gruplar arasında anlamlı bir fark görülmedi (Tablo 2).

Toplam 1173 çocuk hastanın HBsAg, AntiHBc IgM, Anti HBc IgG, AntiHBclg G ve Anti-HCV seropozitiflikleri değerlendirildiğinde; sırasıyla \%2,4, \%79,4, \%0,5, \%10,1 ve \%0,6 olarak saptand. HBsAg ve Anti-HBs birlikte pozitifliği sadece 3 hastada tespit edildi. Hiçbir çocukta Anti-HIV pozitifliği görülmedi.

Anti-HBs ile AntiHbc IgG çocukların 632'sinde birlikte bakılmış ve 39'unda pozitif bulunmuştur $(\% 6,2)$. HBsAg'si pozitif olan 26 hastanın 11'inde aynı zamanda AntiHBc IgM bakılmış ama hiçbirinde pozitif bulunmamıştır. Yaş grupları arasında seropozitiflik oranları yönünden fark olup olmadığı irdelendiğinde anlamlı bir fark olmadığı görülmüştür (Tablo 4) (p>0,05).

Haziran 1998'de ulusal așı programının bașlamasıyla birlikte bu oranlarda değişiklik olup olmadığına bakıldığında Anti-HBc Ig G pozitifliğinin 1998'den sonra doğanlarda daha yüksek olduğu görülmüş ve istatistiksel olarak da anlamlı bulunmuştur. Aynı şekilde pozitif Anti-HBs oranları da 1998'den sonra doğanlarda anlamlı şekilde yüksek bulunmuştur (Tablo 5).

\section{Tartışma}

Hepatit A'da temel bulaş fekal-oral yolladır ve genellikle virüs içeren dışkı ile kontamine olmuş besin ya da su aracılığı ile yayılmaktadır. Ayrıca parenteral yolla ve aile içinde özellikle kalabalık yaşam koşullarında yakın temas sonucu bireyden bireye bulaş gerçekleşebilmekle birlikte olguların önemli bir kısmında bulaş yolu saptanamamaktadır (8-11). Bununla birlikte, cinsel yolla da bulaş olabilmektedir. Özellikle homoseksüeller arasındaki anal-oral ilişki ile yüksek riskte bulaşma olabilir (12). Örneğin Doğu ve Güneydoğu Anadolu Bölgeleri'ndeki şehirlerde, \%74,8'inde enfeksiyon kaynağı tespit edilememiştir (11). Ülkemiz HAV enfeksiyonu açısından genel olarak orta düzeyde endemisiteye sahip bölge olarak değerlendirilmekle birlikte endemisite coğrafi bölgelere ve sosyoekonomik duruma göre farkllıklar gösterebilmektedir (8). Dünyada en düşük prevalans Iskandinav ülkelerinde görülürken, bu ülkeleri Japonya, Avustralya ve bazı Avrupa ülkeleri izlemektedir (8, 13,14). Gelişmiş ülkelerde hepatit A prevalansının azalması; altyapının gelişmesi, yüksek kalitede su temini, el temizliğinin iyi yapılması ve insan atıklarının gerekli şekilde yok edilmesi ile açıklanabilir. Az gelişmiş ve gelişmekte olan ülkelerde ise özellikle alt yapı yetersizliğine bağlı olarak en önemli sağlık sorunlarından biri olmaya devam etmektedir. Bu bölgelerde, gelişmiş ülkelerin aksine virüsle temas genellikle çocukluk çağında olmaktadır. Ülkemizin Erzurum, Şanlıurfa, Malatya, Istanbul, Hakkari, Elazığ, Gaziantep gibi değişik bölgelerinde yapılan çalışmalarda çocuk yaş grubu ele alındığında Türkiye için seroprevalansın \%35-80 arasında değiştiği görülmektedir (8). Bizim çalışmamızda ise \%29,5 gibi bu çalışmalarda bildirilenden daha düşük oran tesbit edilmiştir. Bu durum Rize ilinde sosyoekonomik seviyenin ve hijyen koşullarının daha iyi olmasına bağlanabilir. Hepatit A gelişen olgularda cinsiyet farkı beklenmemekle birlikte erkek oranının fazla olduğu çalışmalar mevcuttur $(15,16)$. Bu çalışmada da Anti-HAV IgG pozitifliği erkek çocuklarda anlamlı şekilde daha yüksek bulunmuştur.

Ülkemizde bölgeden bölgeye değişiklik gösteren HBsAg prevalansı \%4-10, Anti-HBs prevalansı \%20,6-52,3 arasında değişen oranlarda bulunmuş olup, ülkemiz orta endemik bölgeler 
grubuna girmektedir (17).Ülkemizde toplumun genelinde HBV pozitifliği \%1,7-21 arasında bildirilirken 2008 yılında Viral Hepatitle Savaşım Derneği'nin Sağlık Bakanlığı izni ile toplum genelinde yürüttüğü epidemiyolojik bir çalışmaya göre de HBV pozitifliği $\% 2,46$ gibi düşük bir oranda bulunmuştur. Yine bu çalışmaya göre en yüksek oran \%4,1 ile Güneydoğu Anadolu bölgesinde saptanırken en düşük oran \%1,7 ile Karadeniz bölgesinde bulunmuştur (18-20). Çocukluk yaş grubunda yapılmış sınırlı sayıda çalışma bulunmaktadır. Son 20 yıl içinde ülkemizde çocukluk çağında B hepatiti sıklığını araştıran çalışmalar gözden geçirildiğinde bölgesel olarak ve zaman içinde çocuklarda HBV enfeksiyonu sıklığı açısından bazı farklılıklar gözlendiği dikkat çeker. Çocukluk çağını kapsayan diğer çalışmalarda doğuya doğru ilerlendikçe HBsAg ve Anti-HBc pozitiflik oranlarının arttığı ve ilk 6-15 yaş içerisinde sırasıyla \%3,09-9,8 ve \%19,3-20,4'e ulaştı̆̆ı görülür (19-22).

Ülkemiz gibi orta endemik bölgelerde HBV enfeksiyonunun bulaşması daha çok non-parenteral yolla olmaktadır, bunda da düşük sosyo-ekonomik düzeyin etkisi vardır. Özellikle 6 yaş ve altında aile içi yakın temas, yetersiz hijyenik durumlar, aynı havlunun, sakızın veya diş fırçasının paylaşııması gibi faktörler HBV enfeksiyonunun bulaşmasını kolaylaştırmaktadır (23-25). Bu nedenlerden dolayı çocuklarda rutin Hepatit B aşısının yapılması, HBV enfeksiyonunun önlenmesi ve taşıyıcıların azalması yönünden çok önemlidir. Enfeksiyonun yaşamın erken döneminde kazanılmasıyla kronikleşmesi arasındaki ilişki kanıtlandıktan sonra aşılama daha da önem kazanmıştır. 1998 yılından itibaren "Ulusal Hepatit B Aşı Programı"'(UHBAP) çerçevesinde hepatit B aşısı ulusal rutin aşılama takviminde yer almış, yenidoğan döneminden başlanarak 3 doz uygulanmaya başlanmıştır $(25,26)$. Ülkemizin değişik illerinde çocuklarda yapılan çalışmalarda HBsAg pozitifliği \% 0-9,5 gibi oranlarda iken, Anti-HBs pozitifliği aşılama programından önceki yıllarda \%13,3 gibi oldukça düşük iken son yıllarda \%100.0 gibi yüksek oranlara ulaşmıştır. Bu çalışmada AntiHCV pozitifliği değerlendirildiğinde \%0,6 oranı ile diğer çalışmalarla benzer bulunmuştur. Bizim çalışmamızda elde edilen oranlar görüldüğü gibi yıllar içerisinde halkımızın daha çok bilinçlenmesi, büyük şehirlerde sağlık hizmetlerine ulaşımın kolaylığı, hastaların sosyo-ekonomik düzeyinin nispeten yüksek olmasına bağlanabilir. Bu çalışmada; HAV için aşılamanın yanı sıra eğitimle birlikte sanitasyon tedbirlerinin etkin bir şekilde kullanılması ve altyapı eksikliklerinin giderilmesi HAV enfeksiyonun görülme oranını azaltacağı vurgulanmıştır. Ayrıca hepatit B ve hepatit C seroprevalans oranları, ülkemizdeki genel nüfus oranlarıyla uyumludur. Ülkemizde çocukluk çağında HBV ve HCV seroprevalansıyla ilgili daha fazla çalıșma yapılmalıdır. "Ulusal
Hepatit B Aşı Programı" (UHBAP) uygulamasında hedef değerlere ulaşılması için toplumun daha da bilinçlendirilmesi gerekmektedir.

Sağlık Bakanlığının bildirdiği rakamlara göre 2000 yılında ilk yaş grubunda Hepatit B aşısı yapılma oranı \%66 iken, 2004'te bu oran \% 77'e ulaşmıştır (41). Sağlık Bakanlığı'nın 2002-2006 yılı verilerine göre, ülkemizde son beş yılda ortalama rutin HBV aşılanma oranı \% 76,8; Güneydoğu Anadolu Bölgesi'nde ise ortalama \%58.8 olarak bildirilmiştir. Dünya Sağlık Örgütü'ne göre HBV'nin yüksek ve orta düzeyde endemik olduğu bölgelerde, çocukların en az \%90'ının aşılanması gerektiği bildirilmiştir. Ülkemizde Sağlık Bakanlığı'nın hedefi ise, çocukluk çağında rutin HBV aşılama oranının \%95'in üzerine çıkarılmasıdır (25).

Üstün ve ark. nın yaptığı çalışmada UHBAP uygulamasından

Tablo 1. Serum örneğinde anti-HAV IgM ve anti-HAV IgG antikorlarının serolojik profili

\begin{tabular}{lcccc}
\hline & \multicolumn{2}{c}{ Pozitif } & \multicolumn{2}{c}{ Negatif } \\
& \multicolumn{1}{c}{ Sayı } & yüzde & sayı & yüzde \\
\hline Tek başına & & & & \\
anti-HAV IgM & $17 / 682$ & 2,5 & $665 / 682$ & 97,5 \\
$\begin{array}{l}\text { Tek başına } \\
\text { anti-HAV IgG }\end{array}$ & $202 / 684$ & 29,5 & $482 / 684$ & 70,5 \\
$\begin{array}{l}\text { Anti-HAV IgM } \\
\text { ve anti-HAV IgG birlikte }\end{array}$ & & & \\
$\begin{array}{l}\text { pozitifliği } \\
\end{array}$ & & & $175 / 182$ & 96,2 \\
\end{tabular}

Tablo 2. HBV ve HCV testlerinde pozitif ve negatiflik oranları.

\begin{tabular}{lcccc}
\hline & \multicolumn{2}{c}{ Pozitif } & \multicolumn{2}{c}{ Negatif } \\
TESTLER & Sayı & yüzde & sayı & yüzde \\
\hline HBsAg & 26 & 2,4 & 1068 & 97,6 \\
AntiHBs & 724 & 79,4 & 188 & 20,6 \\
AntiHBclgM & 3 & 0,5 & 569 & 99,5 \\
AntiHBclgG & 55 & 10,1 & 491 & 89,9 \\
AntiHCV & 5 & 0,6 & 814 & 99,4 \\
Birlikte HBsAg ve & 3 & - & - & - \\
AntiHBs pozitifliği & & & & \\
AntiHBs+AntiHBclgG & 39 & 6,2 & 593632 & 95,8 \\
Birlikte HBsAg ve & - & - & 11 & 100,0 \\
AntiHBclgM pozitifliği & & & & \\
*P>0,05 & \multicolumn{5}{|l}{} \\
\hline
\end{tabular}

Tablo 3. Yaş gruplarına göre HBV ve HCV testlerinde dağııım

\begin{tabular}{|c|c|c|c|c|c|c|}
\hline & Toplam & $0-2$ yaş & 3-5 yaş & 6-10 yaş & $11-16$ yaş & $\mathbf{p}^{*}$ \\
\hline Anti-HbclgG & 55 & 18 & 14 & 15 & 8 & 0,392 \\
\hline Anti-HbclgM & 3 & 1 & 1 & 1 & - & 0,872 \\
\hline $\mathrm{HBsAg}$ & 26 & 7 & 11 & 7 & 1 & 0,359 \\
\hline Anti-HBs & 724 & 209 & 231 & 160 & 124 & 0,131 \\
\hline Anti-HCV & 5 & 1 & 2 & 1 & 1 & 0,972 \\
\hline
\end{tabular}


sonra, istatistiksel olarak HBV taşıyıcııık oranıyla doğal bağışıklık oranının anlamlı olarak düştüğü ve aşılamaya bağlı izole Anti-HBs pozitiflik oranının da arttığı görüldü. Bu çalışmada HCV açısından seropozitif olgu bulunmadı. (25). Köse ve ark. (4) larının çalışmasında \%64,8 aşılanma oranının bu topluma göre düşük bulunduğu belirtilmiştir.

Bu çalışmada da Anti-HBs ve Anti-HBc lgG pozitifliği 1998'den sonra doğanlarda, önce doğanlara göre anlamlı şekilde yüksek bulunmuştur. Anti-HBs + Anti-HBc IgG birlikte pozitifliği 39/632 çocukta \%6,1 oranında tesbit edilmesi doğal yoldan geçirenin az olduğunu düşündürmektedir. Ülkemizde, 1998'den önce HBV seroprevalansıyla ilgili yapılan çalışmaların çoğu yetişkin bireyleri içermektedir. UHBAP uygulamasından sonra ise çocukluk çağı HBV

Tablo 4. Ulusal aşlama programı öncesi ve sonrasına göre seropozitiflik oranları

\begin{tabular}{lccc}
\hline TESTLER & $\begin{array}{c}\text { 1998'den önce } \\
\text { doğanlar (n/\%) }\end{array}$ & $\begin{array}{c}\text { 1998'den sonra } \\
\text { doğanlar (n/\%) }\end{array}$ & $\mathbf{p}$ \\
\hline Anti-HBs & $95 /(13)$ & $629 /(87)$ & 0,019 \\
HBsAg & $5 /(19)$ & $21 /(81)$ & 0,126 \\
AntiHBc Ig G & $14 /(26)$ & $41 /(74)$ & 0,0001 \\
AntiHBc lg M & $1 /(33)$ & $2 /(67)$ & 0,162 \\
Anti-HCV & $0 /(0)$ & $5 /(100)$ & 0,493 \\
\hline p<0,05 & & &
\end{tabular}

seroprevalansıyla ilgili sınırlı sayıda çalışma yayımlanmıştır (25). Yaş gruplarına göre seropozitiflikler değerlendirildiğinde Atabek ve ark. (33) HBsAg pozitifliğini en çok 13-17 yaş arasında, Kösecik ve ark. (42) Şanlıurfa'da en çok 6-11 yaş arasında bulunmuştur. Bu çalışmada da en çok 3-5 yaş grubunda bulunmuş ancak aradaki fark istatistiksel olarak anlamlı bulunmamıştır. Çocuklarda Anti-HCV pozitifliğini değerlendiren çalışmalarda \%0,0-1,4 oranında saptanmıştır (4). Bu çalışmada da \%0,6 ile diğer çalışmalara benzer bulunmuştur. Sonuç olarak HAV enfeksiyonu ülkemizde hala önemli bir halk sağlığı problemi olmaya devam etmektedir. Bölgemizde hepatit $A$ aşılaması sadece sosyoekonomik düzeyi iyi olan aileler tarafından istenirse çocuklara yapılmakta olup, bağışıklamanın çok düşük oranda kaldığı tahmin edilmektedir. Eylül 2012 itibariyle hepatit A aşısı ulusal aşılama programına dahil edilmiştir. Ayrıca aşılamanın yanı sıra eğitimle birlikte sanitasyon tedbirlerinin etkin bir şekilde kullanılması ve altyapı eksikliklerinin giderilmesi HAV enfeksiyonun görülme sıklığını azaltacaktır. Sağlık Bakanlığı'nın rutin Hepatit B aşılama programı dahilinde olan çocuklar üzerinde yapılmasına rağmen; aşılanma oranı hedef değer olan \%95'in altındadır. Bu oranın düşük olması, rutin aşılama konusunda halkımızın yeterince aydınlatılamadığı gerçeğini gözler önüne sermektedir. Sağlık Bakanlığı tarafından yaklaşık 14 yıl önce uygulamaya başlanan rutin Hepatit B aşısının, ülkemizde Hepatit B enfeksiyonundan ve bunun neden olabileceği diğer hastalıklardan ve ölümlerden korunmada çok yararlı olduğunu ve olacağını

Tablo 5. Ülkemizin değişik illerinde yapılmış olan çalışmaların sonuçları

\begin{tabular}{|c|c|c|c|c|c|c|}
\hline KAYNAK (no) & YER & YIL & HBsAg & Anti-HBs & Anti-HbclgG & Anti-HCV \\
\hline Kuru U. (27) & İstanbul & 1995 & 6,6 & & & \\
\hline Şahin KM. (28) & Çukurova & 1996-1997 & 8 & & & \\
\hline Tansuğ Ş (29). & İmir & & 1,2 & & & \\
\hline Çetinkaya F. (30) & Samsun & 1995 & 3,2 & 13,3 & & \\
\hline Uçar B (31) & Eskişehir & & 0,48 & & & \\
\hline Sidal M. (32) & İstanbul & 2000 & & & 18,6 & \\
\hline Atabek ME. (33) & Konya & 2000 & 0,65 & 1,3 & & 0,33 \\
\hline Ayata A. (34) & Isparta & 2004 & & & & \\
\hline Nalbantoğlu B. (3) & Istanbul & 2008 & 1,0 & 83,1 & & \\
\hline Özen M. (35) & Malatya & 2006 & & 64,4 & 4,9 & \\
\hline Arabacı F. (36) & Van & 2005 & 9,5 & & 17,9 & \\
\hline Şahin Y. (2) & Gaziantep & 2005 & 1,25 & 70,8 & & \\
\hline Süleyman A. (26) & İstanbul & $2005-2007$ & 0,0 & 96,2 & 0,0 & \\
\hline Demirören K. (37) & Ankara & 2007 & & 90 & & \\
\hline Ayvaz A. (38) & Sivas & 2010 & 0,16 & 73,9 & 0,0 & \\
\hline Tosun SY. (39) & Manisa & & & 100,0 & & 0,0 \\
\hline Köse Ş. (4) & Izmir & 2010 & 2,1 & 77,5 & & 0,7 \\
\hline Kaya A. (40) & Van & 2011 & 0,2 & 71,3 & & \\
\hline Rize (bu çalışma) & Rize & 2010-2011 & 2,4 & 79,4 & 10,1 & 0,6 \\
\hline
\end{tabular}


göstermektedir. Aşılama programının özellikle horizontal bulaşmanın olduğu altı yaş ve altı çocuklarda devam etmesi ve halkı bu konuda bilinçlendirmenin daha etkin bir şekilde yapılması ileriki yıllarda aşı yapıma oranının artmasına, HBV infeksiyonunun azalmasına ve dolayısıyla bu infeksiyonun neden olduğu mortalite ve morbiditenin azalmasına neden olacaktır.

\section{Teşekkür}

Çalışmanın istatistik verilerinin elde edilmesinde yardımcı olan Yrd. Doç. Dr. Hüseyin Avni Uydu'ya teşekkür ederiz.

\section{Kaynaklar}

1. Murray PR, Rosenthal KS, Pfaller MA. Tibbi Mikrobiyoloji. Altınc Baskı. Ceviri editörü: Ahmet C. Başustaoğlu. Hepatit Virüsleri Çeviren: Cem Ergon ve Hakan Abacıoğlu.2010.

2. Şahin Y, Aydın D. 6 yas ve altı çocuklarda Hepatit B seroprevalansı. Firat Tip Dergisi. 2005: 10(4): 169-172.

3. Nalbantoğlu B. 9 Ay- 8 yaş arası çocuklarda hepatit B Seroprevalansı ve așılanma durumları (uzmanlık tezi). Istanbul. T.C Sağlık Bakanlığı Zeynep Kamil Kadın ve Çocuk Hastalıkları Hastanesi Çocuk Sağlığı ve Hastalıkları Kliniği.

4. Köse Ş, Ece G, Gözaydın A, Ergin Ö. Izmir Sosyal Hizmetler ve Çocuk Esirgeme Kurumuna (SHÇEK) Bağlı Yetiştirme Yurtlarında Yaşayan Cocuklarda Hepatit B ve Hepatit C Seroprevalansı. Viral Hepatit Dergisi. 2010; 16(2): 64-8

5. Ișık Balcı Y, Polat Y, Övet G, Sarı F, Görüșen I. Denizli ilinde 1-6 yas arası çocuklarda hepatit $C$ seroprevalansı ve aşılanma durumu. ADÜ Tıp Fakültesi Dergisi. 2010; $11(2)$ : 17-9.

6. Mıstık R, Balık I. Türkiyede Viral Hepatitlerin Epidemiyolojik Analizi. Viral Hepatit 2001

7. Kaçmaz B. Ankara ilinde hepatit B ve hepatit C infeksiyonu seroprevalansı. Viral Hepatit Dergisi. 2003; 8: 97-101.

8. Tekay F. Hakkâri Devlet Hastanesine Başvuran 0-14 Yaş Grubu Cocuklarda Hepatit A Sıklığı. Dicle Tıp Dergisi. 2006: 33: 245-7.

9. White DO, Fenner FJ. Medikal viroloji: Picornaviridae, Hepatit A. Ceviri: Doymaz M.Z. 1.Baskı. Istanbul: Nobel Tıp Kitapevleri, 2000: 400-404

10. Ceylan T, Özgüneș N, Ceylan N, Üçıșık AC. 0-15 yas grubu çocuklarda hepatit A ve hepatit B seroprevalansı. Viral Hepatit Dergisi. 1997; 3: 115-7.

11. Uluğ M, Yaman Y, Yapıcı F, Uluğ NC. Cocuk Yaş Grubu Akut Viral Hepatit A Olguları ve Komplikasyonlarının Irdelenmesi. Çocuk Enf Derg. 2010; 4: 65-70

12. Uluğ M, Can Uluğ N. Aile Içi Temas Sonucu Gelişen Belirtisiz Hepatit A Olgular. Yeni Tıp Dergisi. 2011:28: 47-9.

13. Akbulut A. HAV enfeksiyonu. Balık I, Tekeli E ed. Viral Hepatit-2002. Ankara: Viral Hepatitle Savaşım Derneği, 2002: 35-68.

14. Badur S. Hepatit A, B ve D virusları. Ustaçelebi S, Abacıoğlu H, Badur S ed. Moleküler, klinik ve tanısal viroloji. 1.Baskı. Ankara: Güneş Kitabevi, 2004: 175-202.

15. Taşkesen M, Taş MA, Ecer $S$, Özel A, Karabiberoğlu S. Akut vira hepatit A olgularının klinik ve laboratuvar bulgularının değerlendirilmesi. Dicle Tıp Derg. 2008: 35: 155-8.

16. Tekin B. Selçuk Üniversitesi Meram Tıp Fakültesi Klinik Bakteriyoloji ve İnfeksiyon Hastalıkları Kliniği'nde 1990-2004 yılları arası yatıılarak izlenen akut viral hepațit olgularının değerlendirilmesi (Uzmanlık Tezi). Konya: Selçuk Üniversitesi Meram Tıp Fakültesi, Klinik Bakteriyoloji ve Infeksiyon Hastalıkları Anabilim Dalı, 2004.

17. Taşyaran MA. HBV infeksiyon epidemiyolojisi. In: Kilıçturgay $K$, Badur S, eds. Viral Hepatit 2001: 121-128.

18. Evirgen Ö, Önlen Y, Köksaldı Motor V, Mahsereci E, Inci M, Şahin Ş. Hatay lli Hemodiyaliz Hastalarında HBV, HCV Seroprevalansı ve Hepatit B Aşılaması ile Oluşan Antikor Cevabının Değerlendirilmesi. Viral Hepatit Dergisi. 2010; 16(2): 57-63.

19. Gürbüz Y Tosun $S$, Balık I ve ark. Ülkemizde HBVve HCV seroprevalansı değişiyor mu? 2008 yllı verileri. X. Ulusal Viral Hepatit
Kongresi Antalya. 2010:Antalya. p. 107.

20. Ozdemir D, Kurt $H$. Hepatit B Virusu Enfeksiyonlarının Epidemiyolojisi. Tabak F, Balık I, and Tekeli E (eds). ViralHepatit 2007. Istanbul: Viral Hepatitle Savașım Derneği, 2007: 108-17.

21. Emiroğlu HH, Kesecik $M$, Oğuz $S$ ve ark. Şırnaktaki asker ve sivillerde asemptomatik hepatit B virüsü taşıyıcılığı seroprevalansı. Viral Hepatit Derg. 2000; 1: 18-20.

22. Akbulut $A$, Kılıç SS, Felek $S$ ve ark. Elazı̆g ili ve yöresinde hepatit $B$ prevalansının araştırılması. Viral Hepatit Derg. 1995;1: 29-33.

23. Doganci T, Uysal G, Kir T, Bakırtaş A, Kuyucu N, Doganci L. Horizontal transmission of hepatitis $B$ virus in children with chronic hepatitis B. World J Gastroenterol. 2005; 11: 418-20.

24. Ersoy $Y$, Sönmez E, Çetin C, Durmaz R. Aile Içinde Hepatit B Virüsünün Geçişi. Turgut Özal Tıp Merkezi Dergisi. 1997; 4(4): 430-33

25. Üstün C, Başuguy E, Deveci U. Çocuk cerrahi polikliniğine başvuran hastalarda hepatit b ve hepatit c seroprevalansı. Nobel Medicus Online Dergi.

26. Süleyman A, Gökçay G, Badur S, Aykın S, Kılıç G, Tamay Z, et al. Süt cocukluğunda Hepatit B Așısı Uygulanan Cocuklarda Serolojik Durumun Değerlendirilmesi. Mikrobiyol Bul. 2012; 46(1): 47-56.

27. Kuru U, Senli S, Türel L, Kuru N, Bașkent A, Ulucakli O. Age spesific seroprevalance of hepatitis B virus infection. Turk J Pediatr. 1995; 37: 311-8.

28. Şahin KM, Yarkın F, Kocabaş $E$ ve ark. Akut hepatit ön tanılı cocuklarla sağlıklı cocuklarda HAV, HBV ve HCV markırlarının araştıılması. Viral Hepatit Derg 1998; 2: 104-8.

29. Tansuğ Ş, Düzgünsıvacı E, Ünal $Z$, Güvel $H$. Hepatit $B$ virüs enfeksiyonunun seroepidemiyolojik araştııılması-Izmir. Viral Hepatit Derg. 1999; 2: 96-109.

30. Çetinkaya F, Gürses N, Öztürk F. Hepatitis B seroprevalance among children in a Turkish hospital. J Hosp Infect. 1995; 29: 217-9.

31. Uçar B, Akgün Y, Akgün N, ve ark. Eskişehir ilinde yaşayan okul çağı çocuklarında hepatit B seroepidemiyolojisi. Viral Hepatit Derg. 1997; 1: $60-5$.

32. Sidal M, Unuvar E, Oguz F, Cihan C, Onel D, Badur S. Age-spesifik seroepidemiology of hepatitis $A, B$ and $E$ infections among children in Istanbul, Turkey. Eur J Epidemiol. 2001; 17(2): 141-4.

33. Atabek ME, Ural O, Coban H. Konya'da çocuklarda hepatit A, B, C seroprevalansı. Çocuk Sağlığı ve Hastalıkları Dergisi. 2001; 44: 6670.

34. Ayata A, Çetin H, Öktem F. Isparta'da çocukluk çağında Hepatit B seropozitifliği. Tıp Araştırmaları Dergisi. 2004: 2 (1); 19-22.

35. Özen M, Yoloğlu S, Işık Y, Yetkin G. Turgut Özal Tıp Merkezi'ne bașvuran 0-16 yas grubu cocuklarda anti-HBs seropozitifliği. Türk Pediatri Arsivi. 2006; 41: 31-5.

36. Arabacı F, Demirli H. Van'da 6-10 yas grubu çocuklarda Hepatit A ve B seroprevalansı. Infeksiyon Dergisi (Turkish Journal of Infection) 2005; 19: 457-60

37. Demirören K, Deveci U, Demirören S. Sağlık Bakanlığımızın uyguladığı hepatit B aşılarının sağladığı Anti-HBs Değerleri. F.Ü. Sağ. Bil. Derg. 2007: 21: 183-5.

38. Ayvaz A, Nur N, Engin A, Cetinkaya S. Sivas il merkezinde yaşayan ilkokul birinci sınıf öğrencisi çocuklarda hepatit B ve hepatit C yaygınlı̆̆. Türk Ped Arș. 2010; 45: 132-6.

39. Tosun SY, Karaca M, Ertilav M, Akkum K. Sağlık ocaklarında uygulanan Hepatit B aşısının etkinliğinin değerlendirilmesi. Türkiye Klinikleri Pediatri Dergisi 2003; 12: 77-80.

40. Avni Kaya A, Erbey MF, Okur M, Sal E, Üstyol L, Bektaș MS. Van Yöresinde 0-18 Yaşları Arasındaki Çocuklarda Hepatit B Virusu Seropozitifliği ve Assılanma Durumu. J Pediatr Inf. 2011; 5: 132-5.

41. T.C Sağlık Bakanlığı Temel Sağlık Hizmetleri Genel Müdürlüğü, Calıșma Yıllığı, 2004

42. Kösecik M, Nazlıgül Y, Cebeci Y, Dolmaz M, Tatı MM, Emiroğlu MM. Şanlıurfa'da yöresinde Hepatit B virüs taşıyıclığı. Genel Tıp Derg 1997; 7: 129-31. 